\title{
Drivers of regeneration dynamics following salvage logging and different silvicultural treatments in windthrow areas in Slovenia
}

\section{Forest Ecology and Management 409 (2018) 378-389}

\author{
Gal Fidej ${ }^{1}$, Andrej Rozman ${ }^{1}$ and Jurij Diaci*1
}

Oddelek za gozdarstvo in obnovljive gozdne vire, Biotehniška fakulteta, Univerza v Ljubljani, Večna pot 83, 1000 Ljubljana, Slovenia

\begin{abstract}
We studied regeneration dynamics in forests disturbed by three different windthrow events in 2008 in Slovenia to assess the success of natural regeneration vs planting and subsequent silvicultural treatments. Fifty-three plots with planted saplings of Norway spruce and sycamore maple and 50 plots with dominant naturally regenerated saplings were selected in a randomly stratified manner. Sapling characteristics (height, height increment, root collar diameter, free-to-grow score, browsing and micro-site) were assessed in 2012 and 2014. Herbs and seedling establishment were studied in two subplots within each plot. Average seedling density was 13,074 and $14,674 \mathrm{ha}^{-1}$ four and six years after the windthrows, respectively. Seedlings were irregularly distributed, which suggests micro-site differences in regeneration dynamics. The results indicated lower seedling success on sites that were southerly exposed, farther from the forest edge and seed trees, on undisturbed micro-sites and at higher altitudes. On such sites planting was justified. While seedling density indicated a positive relation to herb coverage, sapling survival was negatively associated with it as well as
\end{abstract}


with browsing. Initial sapling height was the strongest predictor of survival. Spruce saplings had the lowest mortality, while shade-tolerant silver fir and beech experienced high mortality. The study indicated a high density and species diversity of naturally regenerated seedlings within windthrow areas, which was reduced by planting, mowing of competing vegetation and protection measures favouring planted saplings. Recommendations for the improvement of silvicultural operations for post windthrow restoration are given.

Keywords: windthrow restoration; natural regeneration; planting; aspect; altitude

\section{Introduction}

Natural disturbances are an intrinsic part of forest ecosystem dynamics (Pickett and White, 1985). However, they raise concerns for forest owners and managers for several reasons. Their intensity and frequency may be increasing because of environmental changes (Kulakowski et al., 2016). Moreover, many forest stands in Europe are even-aged and monospecific, which make them more susceptible to disturbances (Seidl et al., 2011). Numerous studies have indicated that uneven-aged mixed forests are both more resistant and more resilient to disturbances (O'Hara and Ramage, 2013). However, over the last decade the share of forests damaged by natural disturbances has also been increasing in countries where forests have traditionally been managed with uneven-aged silvicultural systems. For example, in Slovenia several windthrows, ice and snow storms and bark beetle outbreaks resulted in an increase in sanitary logging of a third of the yearly harvest (Diaci et al. 2017). In early 2014 an ice storm of a scale unprecedented in modern history damaged about 9,300,000 $\mathrm{m}^{3}$ of trees across more than 600,000 ha (Nagel et al., 2017; Čater and Diaci, 2017). The storm was followed by a bark beetle outbreak that claimed almost the same amount of wood. 
Besides damage to existing stands, disturbances, especially windthrows, create large openings where different successional stadia develop (Fischer et al., 2002; Wohlgemuth et al., 2002; Jonasova and Prach, 2004; Van Couwenberghe et al., 2011). They may be beneficial for early successional flora and fauna on the one hand, but forest protection functions may be negatively affected on the other (Brang, 2001). Still, in some situations within protection forests, leaving damaged timber in place may be an alternative to silvicultural measures (Schwitter et al., 2015). Windthrow may negatively influence the future income of the forest owner if the share of commercially valuable species is low and regeneration is retarded, and its low density does not enable the production of high quality logs (Diaci et al., 2017). Therefore, spontaneous regeneration of windthrow areas is often supplemented by planting. This can significantly shorten the time period needed to reach closed forest (Schönenberger, 2002; Brang et al., 2004) and to achieve the desired mixture of commercially desirable species. But planting, which often requires protection and tending measures, is expensive and may generate problems for the future resistance of stands (e.g. deficient root development, poor match of plant ecotype with site; Balisky et al., 1995). In countries with prevalent closeto-nature silvicultural systems (Pommerening and Murphy, 2004), there has been considerable discussion over the use of artificial versus natural regeneration for the restoration of windthrow areas (Schönenberger, 2002; Schwitter et al., 2015; Brang et al., 2015; Rozman et al., 2015).

Large-scale disturbances after the 1990s prompted extensive research on post-disturbance forest restoration (Mocalov and Lassig, 2002; Ilisson et al., 2007; Peterson and Leach, 2008; Heurich, 2009; Pröll et al., 2015). One of the major outcomes was identification of a great variety of recovery processes that are dependent on the mode and intensity of disturbance, 
pre-disturbance management, method of restoration and site conditions (Jonasova and Prach, 2004; Rozman et al., 2015). In particular, micro-site variability with pre- and post-disturbance features (disturbed soil, woody debris) may significantly influence regeneration dynamics (Haeussler et al., 2002; Hanssen, 2003; Ilisson et al., 2007; Peterson and Leach, 2008). Any attempt to predict regeneration dynamics should therefore carefully address the many factors that can influence post windthrow regeneration. Lack of seed trees and the absence of the mitigating effect of the forest canopy on the microclimate in open areas, damage to advanced regeneration during salvage logging, development of a the dense herb layer and excessive ungulate browsing are often reported as factors that hinder the development of seedlings (Aussenac, 2000; Hanssen, 2003; Mansourian et al., 2005; Kupferschmid and Bugmann, 2005; Rammig et al., 2007; Van Couwenberghe et al., 2010; Kramer et al., 2014; Brang et al., 2015; Fidej, 2017). The share of pioneer tree species in the post-disturbance succession of spruce dominated boreal and Central European forests is higher in areas that were salvaged and have exposed mineral soil, in larger openings and in stands with stronger past anthropogenic impact (Fischer et al., 2002; Jonasova and Prach, 2004; Vodde et al., 2011). However, this has not been confirmed in all studies (e.g. Heurich, 2009; Kramer et al., 2014; Fidej et al., 2016). Newly emerged seedlings may also profit from disturbed soil caused by salvage logging as indicated in studies from Switzerland, Estonia and the eastern USA (Wohlgemuth et al., 2002; Ilisson et al., 2007; Peterson and Leach, 2008).

The amount of coarse woody debris (CWD) within windthrow areas is reduced by salvage logging. However, it is typically more abundant after disturbances than under gradual regeneration felling (cf. Priewassser et al., 2013). CWD represents a seedbed for spruce (Picea abies (L.) H. Karst.) and fir (Abies alba Mill.) (Eichrodt, 1969; Leibundgut, 1982; Milosavljevic, 2015). Decomposed CWD is required for seedling survival (Kupferschmid and 
Bugmann, 2005; Zielonka, 2006) but is not available immediately after a windthrow. Therefore, the role of CWD in occupying micro-sites, preventing erosion and protecting seedlings against browsing and competing vegetation is more important (de Chantal and Granström, 2007, Baier et al., 2007, but see Kupferschmid and Bugmann, 2005).

Aspect, slope inclination and altitude jointly alter the effects of climatic and geomorphological factors on tree regeneration. With increasing altitude, the vegetation period shortens, climatic extremes increase, differences between micro-sites intensify (Senn and Schönenberger, 2001; Cunningham et al., 2006) and thus overall forest recovery is retarded (Brang et al., 2004). With increasing altitude and slope inclination, differences in aspect become more ecologically important. Southerly exposed micro-sites are prone to accumulating organic matter and to drying out (Noble and Alexander 1977; Brang, 1998). Slope inclination can also influence snow and water movement, with subsequent erosion processes that may be unfavourable for forest regeneration (Senn and Schönenberger, 2001; Hanssen, 2003; Baier et al., 2007).

Decisions on post-disturbance forest regeneration following salvage logging are often dichotomous: artificial or natural regeneration. While the former involves several silvicultural measures, the latter commonly does not involve any intervention at all. Silvicultural measures improve planted sapling survival (Haeussler et al., 2002; Jacobs et al., 2004) but may drastically decrease the potential of naturally regenerated seedlings. Among these seedlings are ecologically and economically important tree species, which may increase the value of young, sparsely stocked plantations in large open areas after disturbance, especially when planted stock has a high mortality rate. While numerous studies have assessed the impact of salvage logging on post-disturbance regeneration, the impact of post-disturbance silvicultural 
operations on the development of naturally regenerated seedlings within plantations has rarely been investigated.

The goals of this study were to (1) compare the development of spontaneous seedling establishment within planted areas and areas designated for natural regeneration following windthrow; (2) evaluate the influence of silvicultural operations in plantations on the density, coverage and species composition of naturally regenerated seedlings; (3) compare the success of dominant naturally regenerated saplings with planted saplings; (4) relate regeneration dynamics with abiotic and biotic factors; and (5) to put forward recommendations for the improvement of post-disturbance forest restoration.

\section{Methods}

\subsection{Research sites}

In 2008 three windthrows (July 7, 13 and August 15) damaged forests over large areas in west, north-central and east Slovenia (Fig. 1.; Anonymous, 2009). The highest volume of damaged trees was in Crnivec (hereafter CRN) in north-central Slovenia followed by Bohor (hereafter $\mathrm{BOH}$ ) in the eastern part of the country and Trnovski gozd (hereafter TRN, Table 1) in the west. The three windthrow areas differ with respect to climatic conditions and sites (Appendix B). Precipitation decreases along a W-E gradient from TRN over CRN to $\mathrm{BOH}$, while yearly mean temperatures reflect differences in altitude. The TRN and CRN sites were classified as mixed mountain beech (Fagus sylvatica L.) and fir forest on carbonate and silicate parent material, respectively, while the $\mathrm{BOH}$ area is mostly covered by beech forest sites at different altitudes and on mixed silicate and carbonate parent material (Table 1). 
Stands damaged by the windthrow were mixed; however, the share of spruce was higher compared to natural conditions (Table 1). The former forests were managed with the irregular shelterwood system (Schütz et al., 2016). Dense, mature stands with average growing stock ranging from 300-500 $\mathrm{m}^{3} \mathrm{ha}^{-1}$ were dominant, while established advanced regeneration was sporadically present (Appendix B). Most forests were privately owned, and thus owners were interested in recuperating economic value from disturbed forests as quickly as possible.

Table 1. Characteristics of the study sites within the three windthrow areas

Windthrow area

\begin{tabular}{|c|c|c|c|}
\hline & $\begin{array}{l}\text { Trnovski gozd } \\
\text { (TRN) }\end{array}$ & $\begin{array}{l}\text { Crnivec } \\
(\mathrm{CRN})\end{array}$ & $\begin{array}{l}\text { Bohor } \\
(\mathrm{BOH})\end{array}$ \\
\hline Total annual precipitation (mm) & 2200 & 1700 & $1000-1150$ \\
\hline $\begin{array}{l}\text { Mean annual temperature } \\
\left({ }^{\circ} \mathrm{C}\right)\end{array}$ & $6-7$ & $6-7$ & $8-11$ \\
\hline Altitude (m) & $950-1290$ & $900-1250$ & $300-830$ \\
\hline Slope $\left(^{\circ}\right)$ & $5-20$ & $20-25$ & $17-40$ \\
\hline Aspect & variable & $\mathrm{N}$ and $\mathrm{S}$ & variable \\
\hline Rockiness and stoniness (\%) & 12 & 2 & 2 \\
\hline \multirow[t]{2}{*}{ Parent material } & dolomite and & clay shale and tuff & mixed (carbonate \\
\hline & limestone & & and silicate) \\
\hline Site classification (Braun- & beech & fir beech forest & submontane and \\
\hline \multirow[t]{5}{*}{ Blanquet) } & (Adenostylo- & (Luzulo-Fagetum & montane beech \\
\hline & Fagetum) and & abietosum) & forest (Hacquetio- \\
\hline & silver fir beech & & Fagetum, \\
\hline & forest & & Cardamine- \\
\hline & & & Fagetum) \\
\hline
\end{tabular}


(Omphalodo-

Fagetum)

Tree species composition of potential natural vegetation

Tree species composition of

previous stand and surrounding stands (\%) beech $(50-80)$

fir (5-40), spruce

(5), noble

broadleaves (5)

beech (50-80),

fir $(0-40)$, spruce

(10-20), noble

broadleaves $(0-$

10)

Growing stock of previous stands

$\left(\mathrm{m}^{3}\right)$

Total volume of trees damaged

by the windthrow $\left(\mathrm{m}^{3}\right)$

Opening sizes (ha)

Number of natural regeneration

plots (NP)

Number of planting plots (PP)

Number of sampled openings
$330-480$

430-600

190-280

50,000

350,000

94,000

$7-16$

$16-87$

$1.5-3$

15

28

7

15

31

7

2

In 2008 and 2009 all damaged trees were salvaged and areas designated for planting were planted in 2009 and 2010, while most of the surface was left for natural development. Various species were used for planting, but for comparative reasons we selected only sites where spruce (age 2+2) and sycamore maple (Acer pseudoplatanus L.) (age 2+1) were planted. The individual plantations ranged in size from 0.02 to 1.00 ha. Bare root saplings from local provenances were produced in Slovenia and planted manually in conventional plant holes. 
The planting density was 1600-2800 saplings ha-1 and spacing was regular. Spruce planted saplings were protected from browsing by coating of the terminal shoot, and the surrounding ground vegetation was mowed on a yearly basis. All sycamore maple planted saplings were protected by fine-mesh tubes.

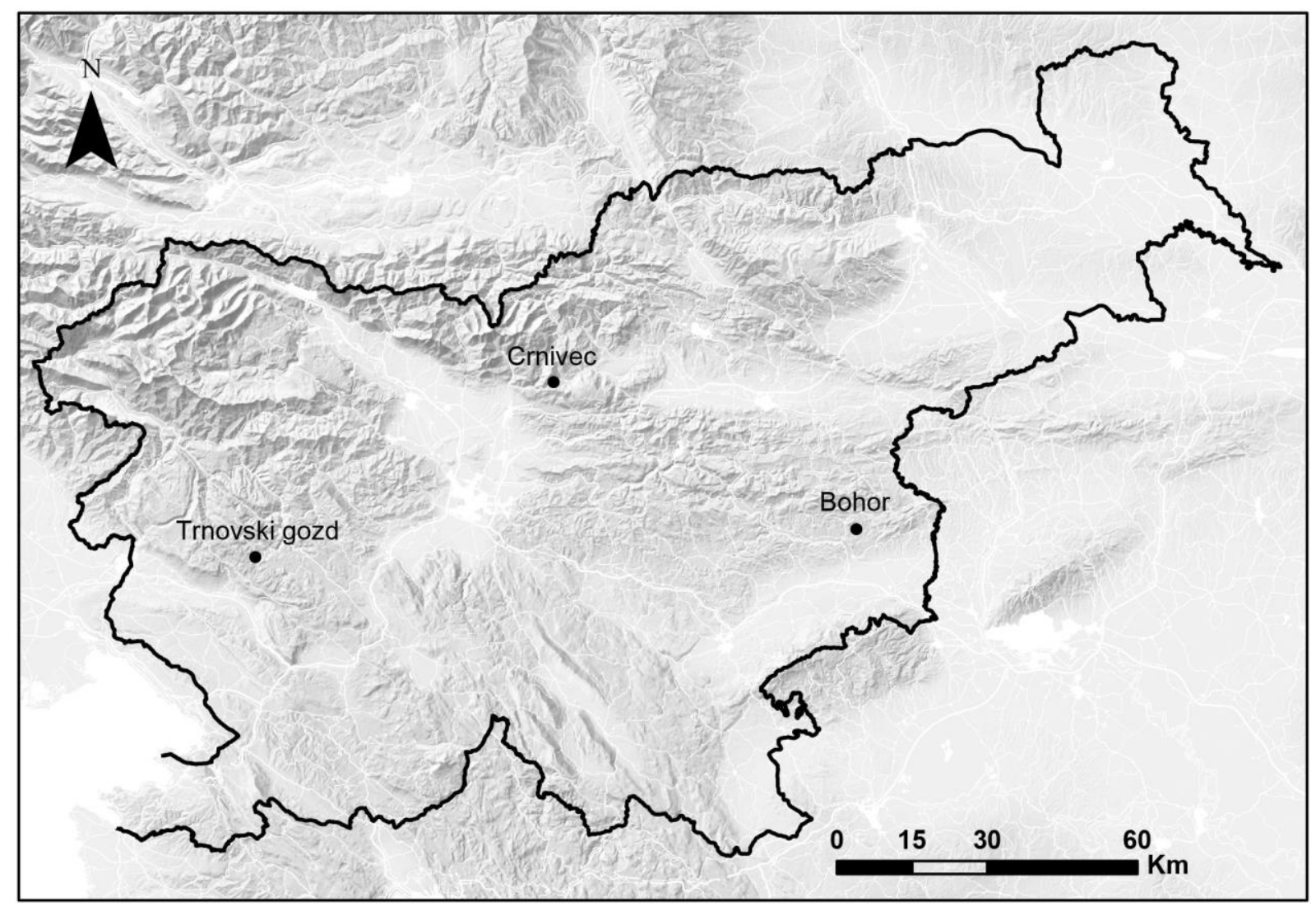

Fig. 1. Location of the three studied windthrow areas from 2008 in Slovenia

\subsection{Field methods}

In 2012 we established 53 planting plots (hereafter PP) 10 x $10 \mathrm{~m}$ in size in localities where planting took place within the three windthrow areas (Table 1). Planting plots were selected in a randomly stratified manner with windthrow areas as strata. Sites with established clusters of pre-disturbance regeneration, forest roads and skidding roads were avoided (Appendix B, Fig. 
B.2). In the nearest vicinity possible to the PP, we placed a natural regeneration plot (hereafter $\mathrm{NP})$ of the same size $(\mathrm{N}=50)$. During the selection of the $\mathrm{NP}$, extreme sites (e.g. rocky outcrops) where no planting took place were avoided. The sides of PP and NP were placed longitudinally and transversely to the maximum slope of the terrain.

To gain insight into the early development of tree seedlings following windthrow, we systematically placed two vegetation subplots $1 \times 3 \mathrm{~m}$ in size left and right of the centre of the PP and NP (Fig. 2). The narrow shape of the vegetation subplots was selected to allow them to be placed between the planting lines and to avoid direct damage to vegetation due to planting and yearly mowing of vegetation surrounding the planted saplings. This was performed manually. The position of all plots and subplots was georeferenced and corners marked with iron stakes.

In 2012 and 2014 all tree seedlings older than one year in vegetation subplots of PP and NP were tallied according to species. In 2012 we also recorded the species composition and per cent cover of all vascular plants per species on the plots. Plant cover was estimated visually from above and was recorded to the nearest $10 \%$ from 10 to $100 \%$, and to the nearest $1 \%$ from $1 \%$ to $10 \%$. The nomenclature source for names of vascular plant taxa was Aeschimann et al. (2004). The coverage of subplots by stones and rocks, CWD and the subplot slope inclination and aspect were assessed. For the analysis, aspect and slope were recoded in a variable with three levels: northerly exposed sites (slope $>10^{\circ}$ and aspect from NW to E), flat sites (slope $\leq 10^{\circ}$ ) and southerly exposed sites (slope $>10^{\circ}$ and aspect from SE to W). Additionally, the shortest distance from each plot to the forest edge and to the nearest seed trees other than the dominant tree species was measured. For the purpose of analyses, woody species were grouped as (1) early successional species (pioneer tree species sensu Davidson, 
1993), (2) light-demanding tree species, and (3) shade-tolerant tree species (sensu Landolt et al., 2010) and shrubs (Appendix C).

Many studies comparing natural and artificial regeneration did not account for the spatial distribution of naturally regenerated saplings, which are often of variable density. To overcome this, the NP were divided into 16 equal quadrants $2.5 \times 2.5 \mathrm{~m}$ in size (Fig. 2). The size of the quadrats was comparable to the size of the growing space of each planted sapling since the lowest planting density was about 1600 seedling ha ${ }^{-1}$. In each quadrant of NP a dominant naturally regenerated sapling (hereafter dominant sapling) with the highest probability of survival based on visual estimation irrespective of the species was selected. Dominant saplings were highly vigorous and not damaged or severely browsed. Often these were the tallest saplings. All planted and dominant saplings were tagged and measured in 2012 and 2014.

In 2012 and 2014 freedom from competition that impedes growth (free-to-grow - FTG; Belli et al., 1999) and browsing damage were assessed for the dominant and planted saplings. Saplings with at least three quadrants free from competing vegetation were considered freeto-grow. Saplings were categorized into one of three browsing classes (undamaged = less than $10 \%$ of the lateral shoots browsed; moderate browsing $=10-50 \%$ of the lateral shoots browsed and/or terminal shoot browsed; severe browsing $=$ more than $50 \%$ of shoots browsed, including the terminal shoot). Sapling height, increment of the terminal shoot for the last three years and root collar diameter were measured. The micro-site characteristics near the seedling were scored: 1 - no special features, 2 - root plate (mound), 3 - pit, 4 - soil damage due to forest operation, 5 - coarse woody debris and 6 - vicinity of tree stump. For 
the analysis the variable was recoded to a binary variable: 1 - undisturbed micro-site and 2 disturbed or covered micro-site.

a) Planting plot (PP)

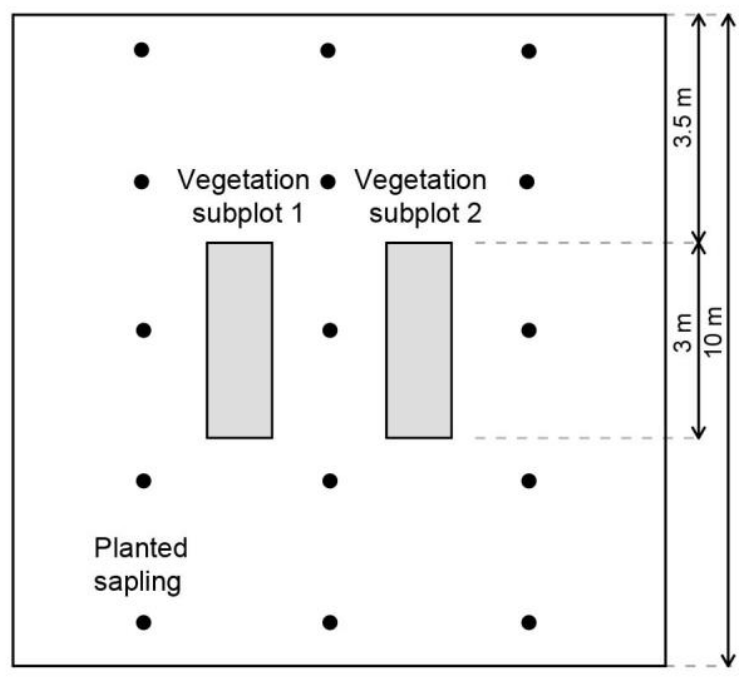

b) Natural regeneration plot (NP)

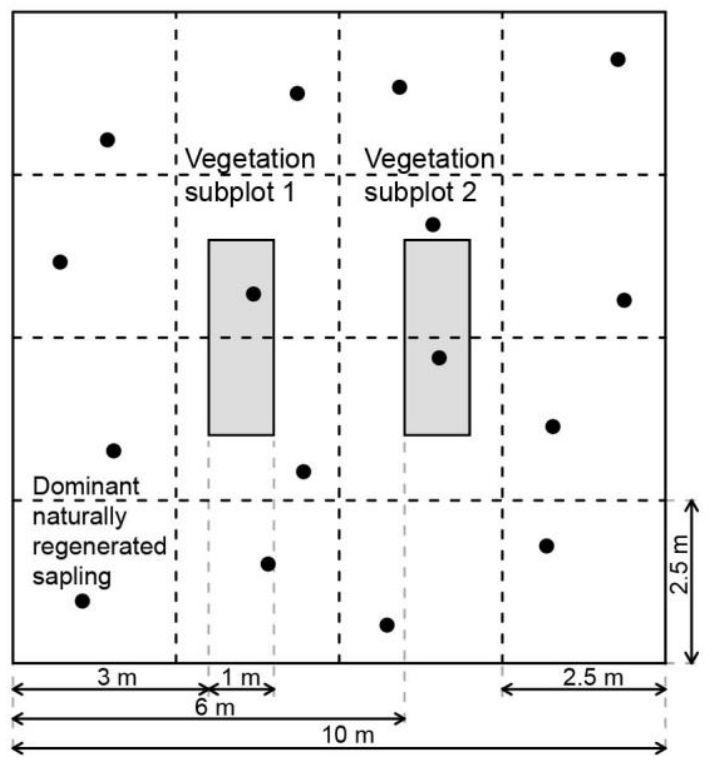

Fig. 2. Schematic presentation of the sampling design: a) planting plot (PP) with vegetation subplots between the rows of planted saplings, b) natural regeneration plot (NP) with quadrants (dashed lines) where a dominant naturally regenerated sapling was selected and tagged if present. 


\subsection{Data analyses}

Data were analysed in R Version 3.3.1 (R Core Team, 2016). The species specific and cumulative yearly mortality rates for planted and dominant saplings were calculated as the percentage lost divided by time. Seedling density in vegetation subplots in relation to ecological factors was modelled with a series of generalised mixed-effects models (GLMMs) with negative binomial distribution and a logarithmic link function (Bolker et al., 2013) since the data were over-dispersed. Seedling coverage in vegetation subplots and characteristics of dominant saplings in NP and PP were modelled with a series of linear mixed-effects models (LMMs). Survival of dominant and planted saplings between 2012 and 2014 was modelled with logistic GLMMs with logit link function (Bates et al., 2015). All final models were selected following a top-down approach (Zuur et al., 2009). Different models with all combinations of ecologically meaningful fixed effects (Tables 2, 3 and 4) were built. These complex models where then compared against simpler nested models based on the restricted maximum likelihood (REML; Pinheiro and Bates, 2000) for LMMs and based on the anova likelihood ratio test of fits for GLMMs (Bolker et al., 2013). Seedling density and coverage models included subplot nested within location as random factors, while survival models included only location. Differences in regeneration variables that were not included in multivariable models were tested with univariate mixed models and $\mathrm{p}$ values are added in brackets. For model diagnostics of all model types, we examined confidence intervals of parameters and analysed sets of graphical summaries proposed by Robinson and Hamann (2011) and Zuur et al. (2009). Based on analysis with the symbox function (Fox and Weisberg, 2011) and inspection of the diagnostic plots, the data were transformed with the square-root or common logarithm function to meet the assumptions of normality and linearity. 
Vegetation patterns were assessed with Detrended Correspondence Analysis of surveys on the vegetation subplots from 2012. Ecological variables, mean Landolt indicator values and seedling density and coverage were fitted onto an ordination plot (see also Appendix A).

\section{Results}

3.1. Vegetation composition and ecological characterisation of sites

In 2012 a total of 17 tree, 16 shrub and 104 herb species were recorded on the vegetation subplots of all three areas. The numbers of tree, shrub and herb species in subplots within NP and PP were similar, and the same was true for the Shannon diversity index. The results of phytoindication with Landolt indicator values (LIV) were similar for both types of plots, the exception being higher values LIV for temperature in PP $(p=0.043)$. On the ordination plot (Fig. 3) both subplot types were not clearly separated, which suggests that site conditions in both plot types were comparable. On the other hand, ordination indicated ecological differences among the three geographically distinct windthrow areas, which were caused by differences in climate and geomorphology (Table 1). All LIV values among areas were significantly different, but only the most ecologically interpretable were presented in Fig. 3. The $\mathrm{BOH}$ area is located at the lowest altitude, has the highest LIV values for temperature and is also the steepest (Appendix B, Fig. B.3). CRN and TRN lie at a higher altitude and exhibit lower coverage of ground vegetation. The higher soil moisture LIV for TRN corresponds with the meteorological data. Density and coverage of shade-tolerant species and pioneer tree species increased towards the swarm of subplots from the CRN region, while light-demanding species increased towards the swarm of plots from BOH. Pioneer tree species density and 
coverage increased with altitude, LIV for light and humus, and distance to the forest edge and decreased with slope inclination and coverage of ground vegetation. Density and cover of shade-tolerant species were inversely related to LIV for soil moisture and nutrients. Indicator species analysis suggested few significant characteristic species: among woody species, only beech and spruce for NP and blackberry (Rubus fruticosus aggr.) for PP.

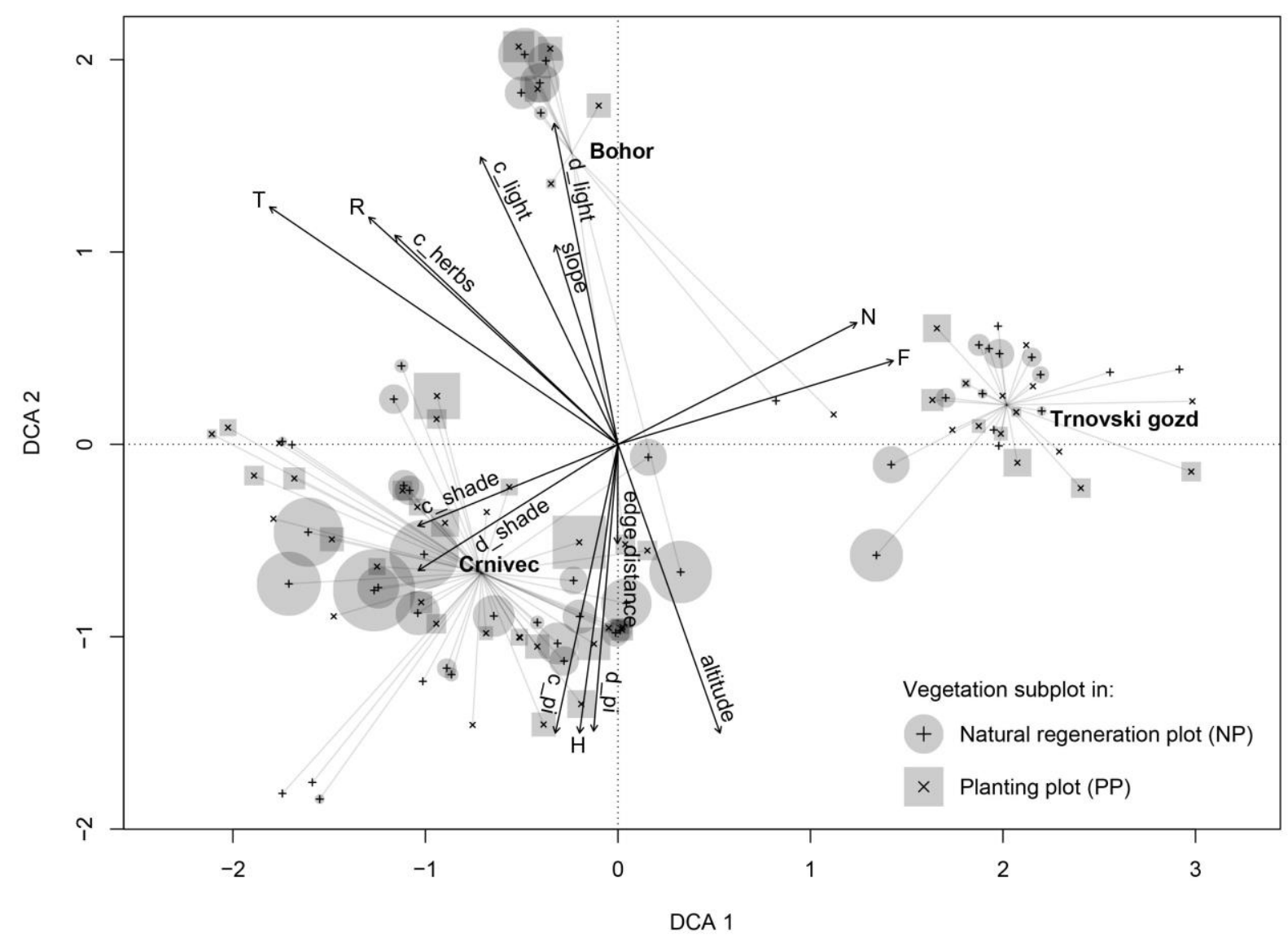

Fig. 3. Detrended correspondence analysis ordination diagram for species composition data from the joint vegetation subplots according to the (a) location and (b) type of regeneration in the space of the first two axes (DCA 1 and DCA 2) that explained most of the variability. The figure shows ecological factors (altitude, distance to stand edge (edge distance), slope inclination), and coverage (c_shade) and density of shade-tolerant (d_shade), light-demanding (c_light, d_light) and pioneer tree species (c_pi, d_pi). Crosses denote vegetation subplots in natural regeneration plots $(\mathrm{N})$ and $\mathrm{x}$ sign in planting plots $(\mathrm{P})$. The size of circles/quadrats is 
proportional to the density of seedlings. The arrows show the direction of the (increasing) gradient, and the length of the arrows is proportional to the correlation between the variable and the ordination. Landolt phytoindication values for temperature $(T)$, soil reaction $(R)$, soil nutrients $(\mathrm{N})$, soil moisture $(\mathrm{F})$ and humus $(\mathrm{H})$ are also drawn. Only factors with p-value $<0.05$ were plotted. Smaller angles between the arrow and axis represent a higher correlation between the two values. Names in bold indicate the three windthrow areas.

\subsection{Natural regeneration on vegetation subplots}

In 2014, six vegetation periods following the windthrows, the average density of seedlings older than one year from all plots reached $14,676 \mathrm{ha}^{-1}$. Seedlings shorter than the ground vegetation canopy, which ranged from 0.10 to $2.0 \mathrm{~m}$, were predominant, but a few taller seedlings, especially pioneer tree species, were also included. Shade-tolerant species prevailed, followed by light-demanding species and pioneer species with $58 \%, 26 \%$ and $15 \%$ of seedling density, respectively. Within the group of pioneer species the most frequent species were goat willow (Salix caprea L.) and silver birch (Betula pendula Roth) with 10\% and $5 \%$ of the total seedling density, respectively, while rowan (Sorbus aucuparia L.) and sycamore maple dominated the group of light-demanding species, with $8 \%$ and $7 \%$, respectively. Within shade-tolerant species spruce and beech prevailed, with $48 \%$ and $9 \%$ of total seedling density, respectively. In both years the mean seedling density was significantly higher in subplots in NP when compared to PP (Table 2, Fig. 4a). For 2014 these densities were 22,727 and 7,292 $\mathrm{ha}^{-1}$ for subplots in NP and PP, respectively. In 2012, merged data from both plot types indicated that seedlings were absent on $33 \%$ of subplots, which increased to $39 \%$ in 2014 . This was due to a steep increase in regeneration-free subplots within PP from $36 \%$ in 2012 to $47 \%$ in 2014, while the share of such subplots declined in subplots within NP 
(30\% vs $28 \%$ ). In both years the lowest seedling density was in the TRN area, where it also significantly decreased between 2012 and 2014 (Fig. 4a). Between these years the density of seedlings in NP also decreased in $\mathrm{BOH}$, while in the same area the density of seedlings in PP increased.

Modelled overall seedling density decreased with CWD coverage and altitude. It increased with distance to the forest edge and herb coverage. The density of pioneer tree species slightly increased with the measurement in 2014. Their density was higher in northerly exposed sites and decreased with increasing slope, while the association with shrub coverage was inversely parabolic. The density of light-demanding trees decreased with CWD coverage and altitude. It was also lower on southerly exposed sites. Further, it was positively associated with the density of shade-tolerant trees and slope steepness, while the association with shrubs was, similar to pioneer tree species, inversely parabolic in shape. Also, the density of shadetolerant trees was lower in subplots in PP. It was positively associated with the density of light-demanding species and with herb coverage, and was higher on flat sites. 
Table 2 Results of the GLMM analysis of natural regeneration density according to tree species groups predicted by factors $(\mathrm{N}=390)$. Research areas and plots within were treated as random effects. Labels in brackets at factor names denote the factor level for comparison, while numbers in brackets within the results denote the standard error (SE).

\begin{tabular}{|c|c|c|c|c|}
\hline & & Pioneer & & \\
\hline Variable & All seedlings & species & Light-demanding & Shade-tolerant \\
\hline Intercept & $2.83(1.05)^{* *}$ & $-0.83(0.83)$ & $-0.24(1.01)$ & $-0.25(0.59)$ \\
\hline Year (2014) & $-0.32(0.15)^{*}$ & $0.39(0.23)^{\circ}$ & $-0.08(0.23)$ & $-0.02(0.22)$ \\
\hline Treatment (planted) & $-1.05(0.14)^{* * *}$ & ns & $\mathrm{ns}$ & $-1.66(0.22)^{* * *}$ \\
\hline Density Pioneer species & $\mathrm{nt}$ & $\mathrm{nt}$ & ns & ns \\
\hline Density Light-demanding & $\mathrm{nt}$ & ns & $\mathrm{nt}$ & $0.31(0.16)^{*}$ \\
\hline Density Shade-tolerant & $\mathrm{nt}$ & ns & $0.09(0.02)^{* * *}$ & $\mathrm{nt}$ \\
\hline CWD coverage & $-0.21(0.08)^{* *}$ & ns & $-0.22(0.02)^{*}$ & $\mathrm{~ns}$ \\
\hline Altitude & $-0.003(0.001)^{* *}$ & ns & $-0.002(0.001) * * *$ & ns \\
\hline Slope & ns & $-0.06(0.02)^{* *}$ & $0.05(0.02)^{* *}$ & $\mathrm{~ns}$ \\
\hline Distance to seed trees & $\mathrm{nt}$ & $\mathrm{nt}$ & $\mathrm{ns}$ & $\mathrm{nt}$ \\
\hline Distance to opening edge & $0.09(0.04)^{*}$ & ns & $\mathrm{nt}$ & ns \\
\hline Herb coverage & $0.30(0.08)^{* * *}$ & ns & $\mathrm{ns}$ & $0.37(0.13)^{* *}$ \\
\hline Shrub coverage & ns & $0.75(0.40)^{\circ}$ & $1.19(0.42)^{* *}$ & ns \\
\hline Shrub coverage $^{\wedge} 2$ & ns & $-0.16(0.07)^{*}$ & $-0.25(0.07)^{* * *}$ & ns \\
\hline Site: northerly vs flat & $\mathrm{ns}$ & $0.83(0.42)^{*}$ & $0.38(0.38)$ & $-0.93(0.33) * *$ \\
\hline Site: southerly vs flat & $\mathrm{ns}$ & $-0.17(0.37)$ & $-0.76(0.38)^{*}$ & $-0.44(0.28)$ \\
\hline Random effects: ${ }^{a}$ Location & $0.40(0.63)$ & $0.86(0.93)$ & $<0.01(<0.01)$ & $0.35(0.59)$ \\
\hline Random effects: Plot in location & $<0.01(<0.01)$ & $0.12(0.35)$ & $<0.01(<0.01)$ & $<0.01(<0.01)$ \\
\hline
\end{tabular}

${ }^{\mathrm{a}}$ For random effects variance and standard deviation in parenthesis are given

Levels of significance: ${ }^{\circ} \mathrm{p}<0.10, * \mathrm{p}<0.05, * * \mathrm{p}<0.01, * * * \mathrm{p}<0.001$

ns: not significant; nt: not tested 

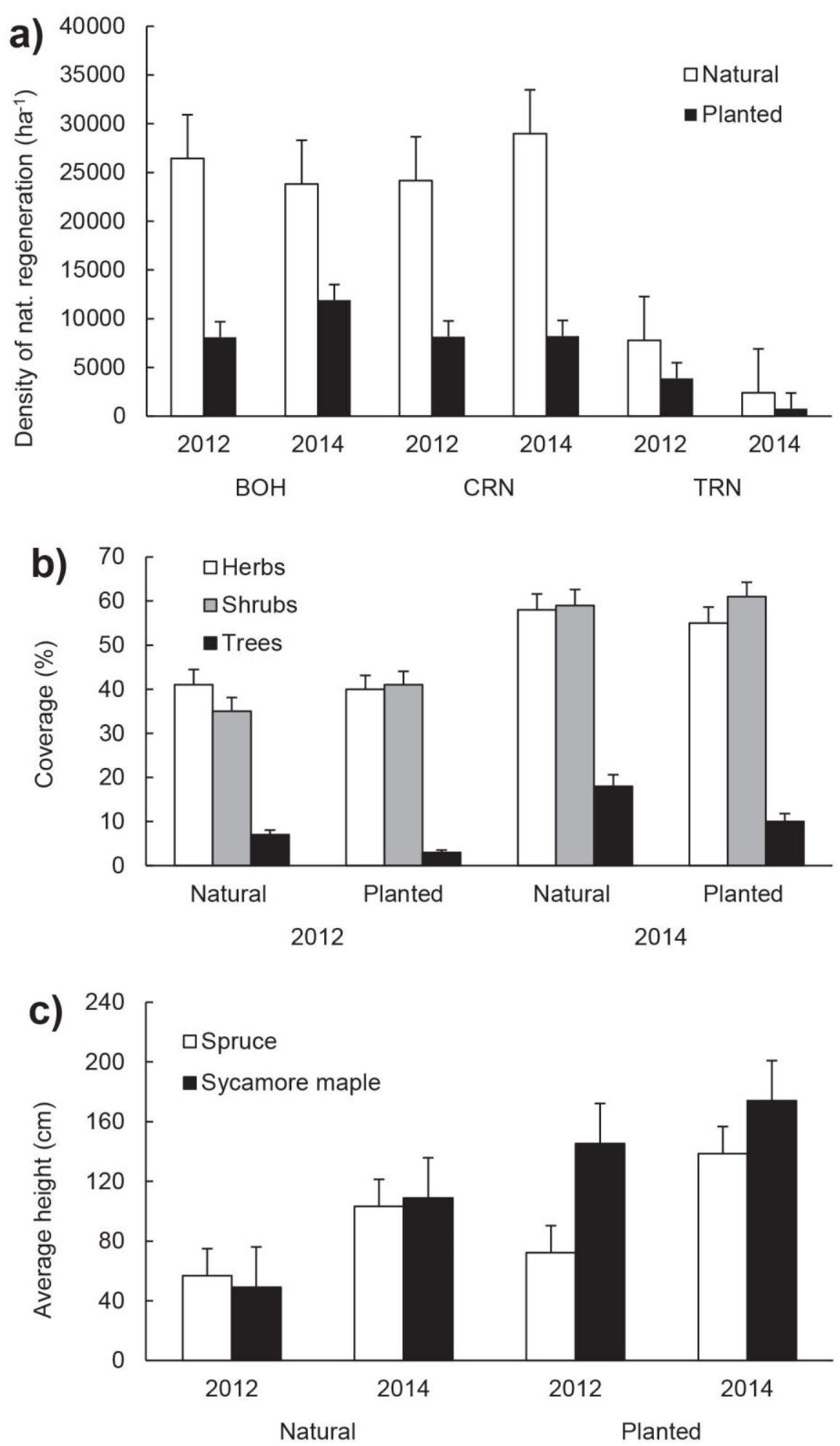

Fig. 4. a) Average density of natural regeneration on vegetation subplots in natural regeneration plots (NP) and planting plots (PP) in three research areas in 2012 and 2014. b) Average coverage of natural regeneration, shrubs and herbs on vegetation subplots in NP and 
PP in 2012 and 2014. c) Average heights of dominant naturally regenerated saplings in NP and planted saplings in PP according to year. All error bars represent standard error.

The total seedling coverage increased with time, from 5\% in 2012 to $15 \%$ in 2014, respectively (Table 3, Fig. 4b). It was positively associated with herb coverage. It was lower on southerly exposed compared to flat sites (8\% vs 14\%, respectively) and on subplots in PP compared to subplots in NP (7\% vs $12 \%$, respectively), and it was negatively associated with altitude. The coverage also increased over time for individual tree seedling groups, as well as for shrubs and herbs (Fig. 4b). The coverage of pioneer seedlings was lowest on southerly exposed sites (2\%) when compared to flat (4\%) or northerly (6\%) exposed sites. Also, the coverage of light-demanding species was highest on northerly exposed sites. It was positively related to slope and negatively related to altitude and distance to seed trees. The coverage of shade-tolerant seedlings was lower on subplots in PP when compared to N. It was highest on flat sites and positively associated with herb coverage. 
Table 3 Results of the LMM analysis of regeneration coverage according to tree species groups predicted by factors $(\mathrm{N}=390)$. Research areas and plots within were treated as random effects. Labels in brackets at factor names denote the factor level for comparison, while numbers in brackets within the results denote the standard error (SE).

\begin{tabular}{|c|c|c|c|c|}
\hline Variable & All seedlings & Pioneer species & Light-demanding & Shade-tolerant \\
\hline Intercept & $4.12(0.79)^{* * *}$ & $0.38(0.26)$ & $2.53(0.43)^{* * *}$ & $0.53(0.25)^{*}$ \\
\hline Year (2014) & $0.38(0.11)^{* * *}$ & $0.38(0.10)^{* * *}$ & $0.05(0.08)$ & $0.18(0.10)^{\circ}$ \\
\hline Treatment (planted) & $-0.36(0.11)^{* *}$ & ns & ns & $-0.50(0.10) * * *$ \\
\hline CWD coverage & ns & $\mathrm{ns}$ & ns & $\mathrm{ns}$ \\
\hline Rockiness & ns & ns & ns & $\mathrm{ns}$ \\
\hline Altitude & $-0.004(0.001)^{* * *}$ & $\mathrm{~ns}$ & $-0.002(<0.001)^{* * *}$ & ns \\
\hline Slope & ns & $\mathrm{ns}$ & $0.02(0.01)^{* *}$ & $\mathrm{~ns}$ \\
\hline Distance to seed trees & $\mathrm{nt}$ & $\mathrm{nt}$ & $-0.07(0.02)^{* *}$ & $\mathrm{nt}$ \\
\hline Distance to opening edge & ns & $\mathrm{ns}$ & $\mathrm{nt}$ & $\mathrm{ns}$ \\
\hline Herb coverage & $0.17(0.06)^{* *}$ & $\mathrm{~ns}$ & ns & $0.17(0.05)^{* *}$ \\
\hline Shrub coverage & $\mathrm{ns}$ & ns & ns & ns \\
\hline Site: northerly vs flat & $-0.16(0.16)$ & $0.26(0.14)^{\circ}$ & $-0.11(0.15)$ & $-0.51(0.14)^{* * *}$ \\
\hline Site: southerly vs flat & $-0.50(0.15)^{* * *}$ & $-0.38(0.13)^{* *}$ & $-0.35(0.14)^{*}$ & $-0.39(0.13)^{* *}$ \\
\hline Random effects: ${ }^{a}$ Location & 1.09 & 0.37 & 0.36 & 0.23 \\
\hline Random effects: Plot in location & $0.17(1.08)$ & $0.13(0.95)$ & $0.07(0.76)$ & $<0.01(0.98)$ \\
\hline
\end{tabular}




\subsection{Development of planted and dominant saplings}

In 2012 we tallied 1035 dominant saplings ha ${ }^{-1}$ on NP and 1480 planted saplings ha-1 on PP (p $=0.0260)$. Both were irregularly distributed with some plots having very high densities and others low densities. Medians of free-to-grow quadrants were significantly lower for dominant saplings when compared to planted saplings and amounted to 2 vs 3 and 1 vs 3 for 2012 and 2014, respectively. Species composition also differed. In NP spruce (42\%), beech $(17 \%)$ and sycamore maple (15\%) represented $74 \%$ of the dominant saplings, while $98 \%$ of the planted saplings were composed of spruce (70\%) and sycamore maple (28\%).

After two years the average density of dominant saplings decreased to 898 seedlings $^{-1}$, and the average density of planted saplings to $1348 \mathrm{ha}^{-1}(\mathrm{p}=0.0160)$. The yearly mortality rate for dominant saplings reached $6.6 \%$ and for planted saplings it was $4.5 \%$. Within the most frequent dominant saplings the highest mortality was recorded for silver fir (30.3\%), followed by sycamore maple $(7.1 \%)$ and beech $(6.8 \%)$, while the lowest mortality was recorded for spruce $(2.5 \%)$. Also, among planted saplings, spruce experienced the lowest mortality (2.9\%). It was followed by sycamore maple (7.1\%), while the highest mortality was recorded for beech and wild cherry (Prunus avium L.) and amounted to $37.5 \%$ and $13.6 \%$, respectively.

In 2012 the height of dominant and planted saplings reached 70.3 and $96.4 \mathrm{~cm}(\mathrm{p}<0.001)$, respectively (Fig. 4c). It increased to 129.5 and $150.4 \mathrm{~cm}$ for dominant and planted saplings in 2014 (p < 0.001), with an average height increment for 2014 of $26.7 \mathrm{~cm}$ and $29.7 \mathrm{~cm}(\mathrm{p}<$ 0.001), respectively. In the same year the root collar diameter of dominant and planted saplings amounted to 21.9 and $29.1 \mathrm{~mm}$ ( $\mathrm{p}<0.001)$, respectively, which amounts to an 11 $\mathrm{mm}$ and $14 \mathrm{~mm}$ increase compared to 2012. In both years spruce and sycamore maple were 
taller in PP when compared to NP (Fig. 4c). Sycamore maple was taller than spruce, except in NP in 2012.

The regression model predicted that the survival of dominant and planted saplings would increase with initial tree size, low browsing damage, in plots on disturbed or partially covered micro-sites and in plots with high FTG values (Table 4). Since spruce and sycamore maple were the most frequent saplings ( $81 \%$ of all recorded saplings), their survival was modelled separately. It was higher for naturally regenerated saplings. As with all saplings, it also increased with initial seedling height and was higher on disturbed micro-sites (Fig. 5). Additionally, the survival of both species was positively associated with northerly exposure and proximity to the forest edge. The survival of spruce was higher than that of sycamore maple (94\% vs $86 \%$ ). The survival of both species increased with altitude, but spruce exhibited a steeper increase. 
Table 4 Negative binomial regression model parameter estimates for models predicting survival of all planted and dominant naturally regenerated saplings $(\mathrm{N}=1157)$ between 2012 and 2014 depending on selected ecological factors. The same model was also developed separately for spruce and sycamore maple. Numbers in brackets denote the standard error (SE).

\begin{tabular}{|c|c|c|}
\hline & All saplings & $\begin{array}{l}\text { Spruce and } \\
\text { sycamore maple } \\
\text { saplings }\end{array}$ \\
\hline Intercept & $0.82(0.67)$ & $1.59(1.23)$ \\
\hline Treatment (planted) & ns & $-1.29(0.41)^{* *}$ \\
\hline Sapling height in 2012 & $0.26(0.05)^{* * *}$ & $0.36(0.07)^{* * *}$ \\
\hline Micro-site (undisturbed) & $-0.82(0.31)^{* *}$ & $-0.92(0.38)^{*}$ \\
\hline Free-to-grow (supressed) & $-0.47(0.24)^{*}$ & ns \\
\hline Browsing 2012 (no vs medium) & $0.19(0.34)$ & ns \\
\hline Browsing 2012 (no vs strong) & $-0.96(0.46)^{*}$ & ns \\
\hline Species (spruce) & $\mathrm{nt}$ & $-0.64(1.15)$ \\
\hline Site (other) & ns & $-0.78(0.30)^{* *}$ \\
\hline Altitude & ns & $0.001(0.001)$ \\
\hline Distance to forest edge & ns & $-0.56(0.29)^{*}$ \\
\hline Species : Altitude & ns & $0.002(0.001)^{*}$ \\
\hline Random effects: ${ }^{\mathrm{a}}$ Location & $0.48(0.69)$ & $<0.001(<0.001)$ \\
\hline \multicolumn{3}{|c|}{ For random effects variance and standard deviation in parenthesis are given } \\
\hline Levels of significance: $* \mathrm{p}<0.05$ & $0.01, * * * \mathrm{p}$ & 01 \\
\hline
\end{tabular}




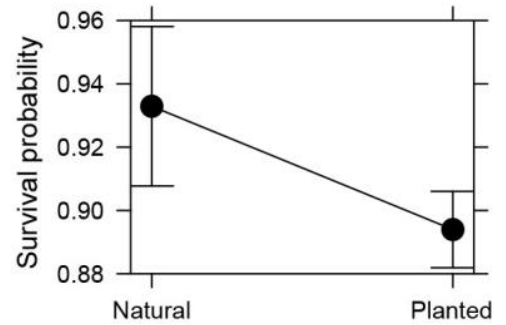

Type of regeneration

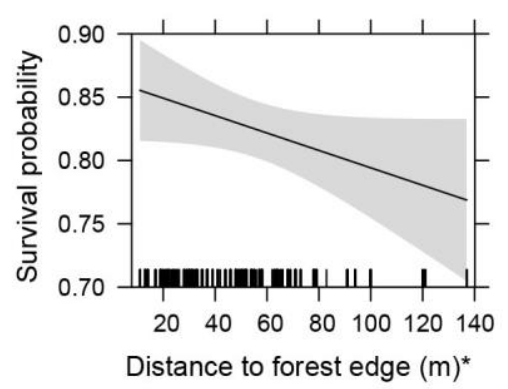

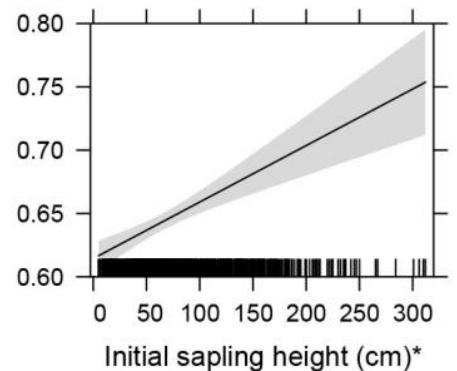

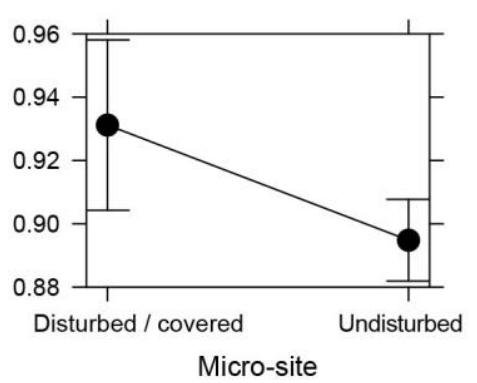

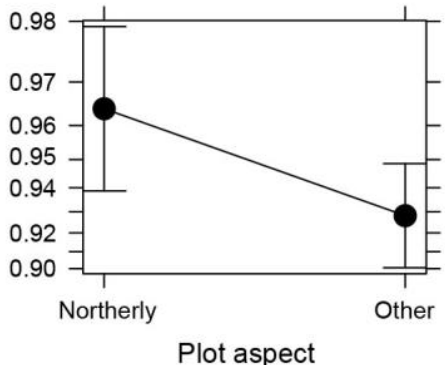

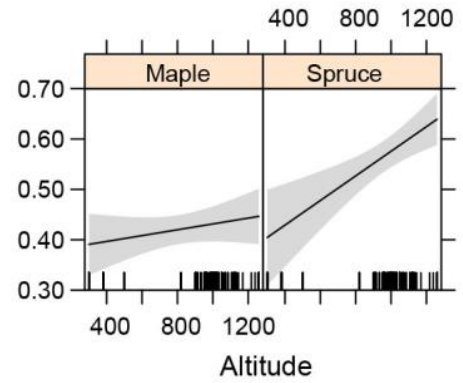

Fig. 5. Predicted survival probability of spruce and sycamore maple saplings with $95 \%$ confidence intervals (grey area or error bars) as a function of type of regeneration (dominant naturally regenerated vs planted saplings), initial sapling height (2012), plot aspect (northerly vs other), distance to the forest edge, micro-site and interaction between species and altitude $(\mathrm{N}=1157) . *$ Initial seedling height and Distance to forest edge were square root and log transformed in the original model.

\section{Discussion}

\subsection{Seedling establishment and impact of silvicultural operations}

The seedling density was at the upper limit of similar studies in Slovenia (Ščap et al., 2013),

Central and Western Europe (Wohlgemuth et al., 2002; Fischer et al., 2002; Van

Couwenberghe et al., 2010; Brang et al., 2015), Estonia (Ilisson et al., 2007 ) and the Urals (Mocalov and Lässig, 2002) 5 to 15 years after windthrow, with values varying in a wide range from 2,000 to $53,000 \mathrm{ha}^{-1}$, but most frequently around $10,000 \mathrm{ha}^{-1}$. This was partly due 
to the low lower age limit (i.e. older than a year) for selecting dominant saplings in this study and higher seedling densities at the lower altitudes of windthrow area BOH (cf. Brang et al., 2015). Shade-tolerant species were dominant, especially spruce. This is similar to other studies (Heurich, 2009; Ščap et al., 2013; Pröll et al., 2015), but contrary to the study by Schönenberger (2002), where sycamore maple was most frequent. The mentioned studies were carried out in spruce dominated stands, but there were differences in sites, and subtle dissimilarities in the distribution of seed trees may also cause different outcomes. We found only a few one-year-old seedlings in both inventories, and seedling density did not increase significantly with time, which indicates that the main wave of seedling establishment is declining and an autoreduction process is in place. However, some studies of post disturbance regeneration indicated a gradual increase in the number of seedlings over extended periods of time, especially within microsites with low seedling density (cf. Heurich, 2009; Brang et al., 2015). We expect that on individual microsites, species well-equipped to compete with ground vegetation may be successful (e.g. sycamore maple), which is why the future young forest will be of variable density.

In 2014 the average naturally regenerated seedling coverage (15\%) was still low. Furthermore, almost $40 \%$ of subplots did not have any seedlings. The share of plots without regeneration was higher than in other similar studies, where it varied from 6 to $29 \%$ (Schönenberger, 2002; Heurich, 2009; Couwenberghe et al., 2010; Ščap et al., 2013). However, the share was lower than that reported for more extreme sites in the Alps (Pröll et al., 2015) or after clear-cuts in Nordic countries (Holgen and Hanell, 2000; Hanssen, 2003). The results of this study indicate that in more than half of the windthrow area, natural regeneration was sufficient (i.e. typically exceeded the average contemporary planting density), especially where well established shade-tolerant species dominated (mainly spruce 
and beech); nevertheless, parts of the area will probably experience log-term succession before becoming a commercial forest. Also, previous studies indicated notable micro-site differences in the regeneration dynamics of mountain forests following windthrow (Wohlgemuth et al., 2002; Peterson and Leach 2008; Pröll et al., 2015). Silvicultural measures, such as planting, installing protective tubes and yearly mowing of competing vegetation, disturbed natural succession. This resulted in a three-fold reduction in seedling density, a nearly $50 \%$ reduction in coverage and a lower share of shade-tolerant species.

\subsection{Assessment of natural regeneration and planting}

The structure of dominant as well as planted saplings indicates the forest composition of the near future. This is important for comparison of natural and artificial regeneration and decisions on future silvicultural interventions. In 2014 the density of planted saplings surpassed the density of dominant saplings by $50 \%$. Since both densities were evaluated according to the quadrants covering the whole research area, this indicates that planted saplings occupy about a quarter larger space. Likewise, most other parameters, such as height, height increment and root collar diameter, were in favour of planted saplings. Due to yearly mowing of surrounding vegetation, in 2014 planted saplings had about 50\% more space for free growth. Also, other studies indicate that the competition of ground vegetation may severely retard the development of regeneration in open areas (Schönenberger, 2002; Fischer et al., 2002; Hanssen, 2003; Jacobs et al., 2004; Ilisson et al., 2007; Van Couwenberghe et al., 2011; Pröll et al., 2015). Dominant saplings were mostly broadleaves that reflect potential natural vegetation, in contrast to planted saplings with spruce as the main species (cf. Brang et al., 2004; Jonasova and Prach, 2004). 
The dominant and planted sapling mortality rate (6.6\% vs $4.5 \%)$ was higher when compared to that found in the Swiss Alps by Schönenberger (2002), who reported < 1\% yearly mortality rate for naturally regenerated saplings of mainly sycamore maple, spruce and pioneer tree species and $1-3 \%$ for planted saplings (mostly sycamore fir, spruce and pioneer tree species) for the first ten years. Conversely, the mortality rate in this study was lower than that reported in studies from Scandinavia (Holgen and Hanell, 2000; Hanssen, 2003). Naturally regenerated saplings in our study had a slightly higher mortality rate than planted saplings, which is in contrast to comparable studies indicating lower mortality rates of naturally regenerated saplings (Holgen and Hanell 2000; Schönenberger, 2002). This was likely due to the fact that in this study dominant saplings were relatively short $(<10 \mathrm{~cm})$ in some quadrants, were often shade-tolerant species such as fir and beech, and, unlike planted seedlings, were not protected against browsing. Spruce had significantly lower mortality compared to other species in both seedling groups, while shade-tolerant species such as beech and fir experienced high mortality. This could be explained by their higher susceptibility to the climatic extremes of open areas (e.g. Diaci, 1996; Landolt et al., 2010; Rozman et al., 2015; Čater and Diaci, 2017), but competition and browsing may have also interfered.

\subsection{Ecological factors and regeneration dynamics}

The 14 ecological factors tested in the models (see Tables 2-4), besides year and type of regeneration, could be classified into two groups. The first group comprises factors that were included in several prediction models, and their behaviour remained consistent across all models. The second group comprises factors that were included in only a few models or those 
whose performance was not consistent. Site aspect was the factor most often included in the models. Southerly exposed sites repeatedly proved to be unfavourable for seedling development, while flat and northerly exposed sites exchanged roles as the most favourable positions. Southerly exposed sites experience greater microclimatic variability, and the soils are prone to drying out (Noble and Alexander 1977; Brang, 1998; cf. Cunningham et al., 2006). This was also supported by the LIV analysis in this study, which indicated drier soils and a deeper humus layer on southerly exposed micro-sites.

The altitudinal range in this study covered almost $1000 \mathrm{~m}$. With increasing altitude the climate cools, climatic differences increase, soil development is retarded and precipitation increases (Senn and Schönenberger, 2001). Altitude was included in most models in this study, and it was largely negatively associated with the predicted factors. The lowest seedling densities and highest dominant sapling mortality were recorded in the TRN area at the highest altitude. This is consistent with the findings of other studies (Senn and Schönenberger, 2001; Brang et al., 2004; Cunningham et al., 2006). A significant increase in spruce survival with altitude may be explained by spruce realized niche (Landolt et al., 2010), while the survival of both species may be facilitated by decreasing ground vegetation coverage with altitude (see also Appendix B, Fig. B.2).

Ground vegetation is reported in many studies as the main hindrance for seedling development overall (Holgen and Hanell, 2000; Diaci, 2002), especially in open areas (Wohlgemuth et al., 2002; Kupferschmid and Bugmann, 2005; Rammig et al., 2007; Rozman et al., 2015). In this study we found a negative relation of herb coverage with shrubs and surprisingly, a positive one with seedling density and coverage. This was probably due to the large proportion of seedling-free sites, where, in addition to an absence of woody plants, 
ground vegetation was also poorly developed. It seems that in the first years after the disturbance, facilitation or neutrality are more important than competition (cf. Haeussler et al., 2002). This was also suggested by the shrub coverage, which exhibited an inversely parabolic association with pioneer and light-demanding species; their lowest densities were in areas with low (extreme sites) and high shrub cover (mesic sites). The positive association between the density of shade-tolerant and light-demanding species may also support this assumption. The association of light-demanding species with northerly exposed sites may indicate the extreme conditions of forest sites following disturbance. On extreme sites otherwise competing species may function as nurse plants (cf. Holgen and Hanell, 2000). On the other hand, the negative impact of ground vegetation was reflected in the survival models, where higher overall sapling survival was linked to taller and ground vegetation free saplings (FTG) and micro-sites with disturbed or covered ground. It seems that in open areas, seedling establishment may better develop in less extreme sites which may already be overgrown by ground vegetation, but succeeding developmental stages are retarded by its competition. Dominant and planted sapling survival was also positively related with sapling height and negatively related to excessive ungulate browsing, both of which have often been reported in studies (Belli et al., 1999; Kupferschmid and Bugmann 2005; Cunningham et al., 2006; Ilisson et al., 2007 ; Rammig et al., 2007).

As reported in other studies (Hanssen, 2003; Mansourian et al., 2005; Van Couwenberghe et al., 2010; Rozman et al., 2015), micro-sites near the forest edge are often associated with better conditions for regeneration due to the proximity of seed trees and the special transitional microclimate between the forest interior and open areas. In this study the results were not entirely consistent, since overall seedling density increased with distance to the forest edge, while overall sapling survival and coverage of light-demanding species 
decreased. This was probably due to the small pre-disturbance regeneration, especially that of spruce, which was covered by ground vegetation and was not excluded during selection of the research plots.

On the one hand, CWD inhibits the development of vegetation, but on the other hand it may decrease erosion and protect seedlings against browsing (de Chantal and Granström, 2007; Rammig et al., 2007). In this study, similar to the results of Kupferschmid and Bugmann (2005), CWD was negatively associated with seedling density and herb cover. Accelerated organic matter decomposition and increased water runoff in windthrow areas may result in eroded and rockier sites, especially on limestone (Rozman et al., 2015). In this study rockiness was included only in the model for prediction of vegetation coverage, which may be due to low overall rockiness (Table 1). Slope inclination accelerates the erosion process and surface water runoff, hinders plant establishment and exacerbates microclimatic extremes on micro-sites (Hanssen, 2003; Baier et al., 2007). Slope inclination by itself was not a major influential factor in this study. It was positively associated with the density of lightdemanding species and negatively associated with pioneer species. This may be due to the partial confounding of slope and altitude, since the lowest elevations, with a high share of light-demanding species, had slightly steeper slopes than average.

\subsection{Conclusions}

In this study, planted saplings possessed several more favourable characteristics than dominant naturally regenerated saplings: height, root collar diameter, increment, density, mortality and better spatial distribution. This was the result of the growth advantage, selected 
planting stock and silvicultural measures. On the other hand, the composition of naturally regenerated saplings was more similar to the potential natural vegetation and will thus form stands that are better adapted to the future climate. The cumulative density of naturally regenerated dominant saplings and seedlings seems appropriate to restore forests capable of delivering many ecosystem services. Nevertheless, it is important to consider that many parts of the windthrow areas had little or no regeneration, which may result in poor tree architecture. Also, competing herb and shrub vegetation coverage was increasing faster than seedling coverage, and a quarter of the dominant naturally regenerated saplings consisted of non-commercially valuable species (e.g. mainly pioneer trees, rowan). Therefore, in some situations, for example in privately owned forests where owners depend on sufficient recovery over entire areas, or where forests are expected to deliver particular ecosystem services (e.g. restoration of protection functions against natural hazards), silvicultural interventions may be necessary. In the above mentioned situations, artificial regeneration may be recommended where many negative factors interact, for example scarce pre-disturbance regeneration $(<$ $\left.1000 \mathrm{ha}^{-1}\right)$, dense ground vegetation coverage (> 80-100\%), southerly exposed sites, microsites far from the forest edge and seed trees (> two tree heights), overbrowsing and high altitudes (> $1000 \mathrm{~m}$ a.s.1.). Future comparisons of restoration treatments should also include controls without salvage logging if forest health issues permit, since this may accelerate the development of climate-resistant and resilient forests.

The study further indicated the high potential of naturally regenerated seedlings in unplanted as well as in planted areas. Silvicultural operations increase the probability of survival of planted saplings, but they may damage naturally regenerated seedlings. Current practices may be enhanced if workers identify target species among naturally regenerated saplings, permanently mark them with poles and favour them with silvicultural measures. Since this 
can be done simultaneously with tending of planted saplings, it also implies a reduction in tending costs. Moreover, in areas with high potential of naturally regenerated saplings, planting density may be reduced. High mortality rates for shade-tolerant saplings, especially fir and beech, indicate that they are less appropriate for the regeneration of exposed sites within large windthrow areas. Planted sycamore maple saplings were less vigorous than spruce, and their mortality was significantly higher despite protection against browsing; this requires a critical analysis of the whole planting system. For planting and selection of dominant saplings for crop trees, taller plants with a better root/shoot ratio and disturbed micro-sites should be preferred. Overall browsing intensity had a negative impact on sapling survival and should therefore be evaluated, and controlling fences and culling measures applied if needed.

\section{Acknowledgements}

This work was supported by the Slovenian Research Agency (ARRS) (Programme group P0059) and Ministry for Agriculture, forestry and food as part of the project "Assessment and optimization of planning and realisation of young forest tending in Slovenia" as well as by the Pahernik Foundation. 


\section{Appendix A: Additional information for the analysis of vegetation}

To assess vegetation patterns, indirect gradient analysis was carried out on the 2012 vegetation survey data. Species coverage data from two adjacent herb subplots were combined, and the 4-th roots of the plant species coverage data were used in the analysis. Due to the high $\beta$-diversity observed among plots, unimodal Detrended Correspondence Analysis was used (DCA) rather than a linear model. Ecological variables (distance to opening edge, altitude and slope), mean Landolt indicator values (LIVs) for the assessment of site conditions (temperature regime, light quantity, soil moisture, soil reaction, nutrient and humus content in the soil) (Landolt et al., 2010), and seedling density and coverage according to species groups were fitted onto an ordination using the vegan package (Oksanen et al., 2016).

Mean LIVs were estimated as a weighted average of the Landolt indicator values of all present species, their abundances being used as weights (Diekmann, 2003). A permutation test was used for assessing the significance of fitted mean LIV and species groups vectors, and only significant factors were plotted onto the DCA plot. Species preference for NP and PP was determined by indicator species analysis (Dufrene and Legendre, 1997) using the indicspecies package (De Caceres and Legendre, 2009). Species diversity on the vegetation subplots was estimated by using the Shannon diversity index, and the differences between NP and PP were determined with a LMM with location as a random effect and true diversities derived from the Shannon indices (Jost, 2006) as a response variable. 


\section{Appendix B: Photographs of the three research areas}

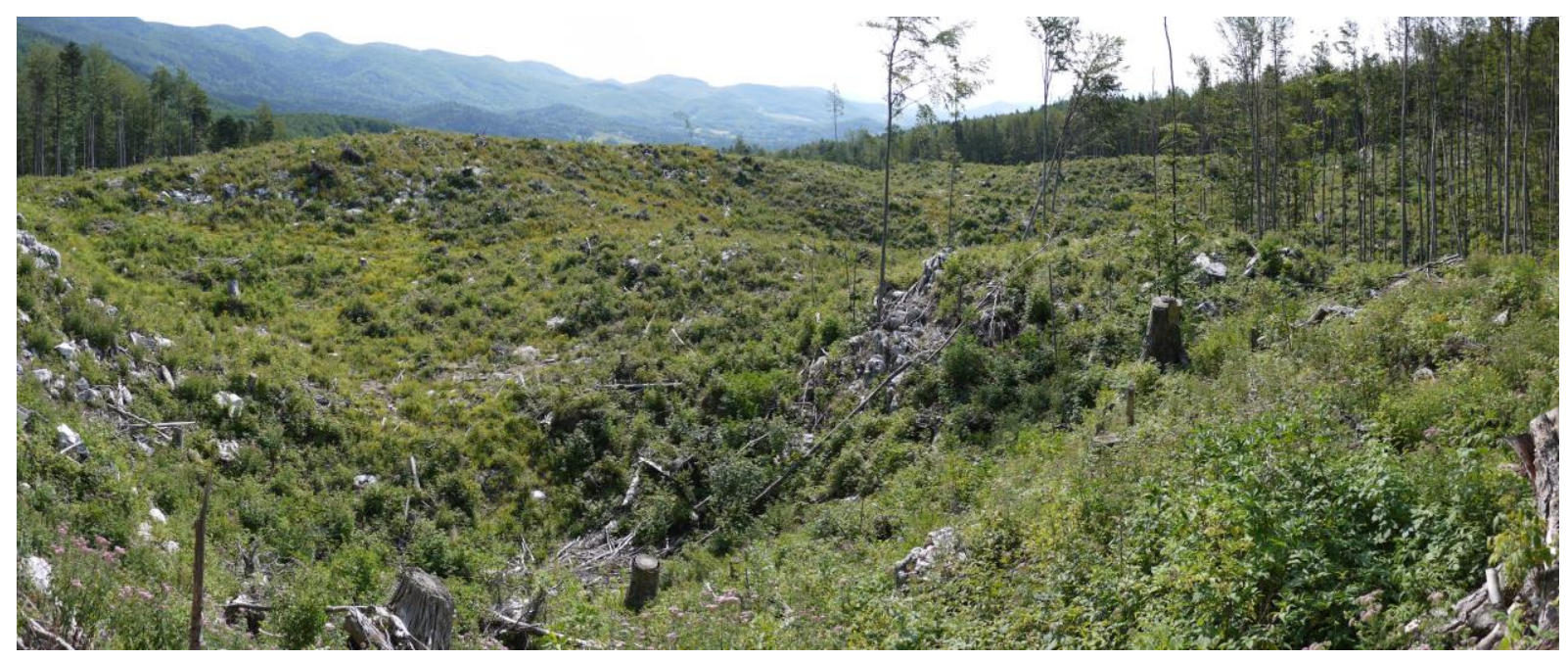

Fig. B.1 The lower part of the windthrow area in Trnovski gozd in May 2012. The windthrow damaged forests at the highest altitudes (950-1280 $\mathrm{m}$ a.s.l.), and the geological substrate is limestone. The site conditions were therefore extreme.

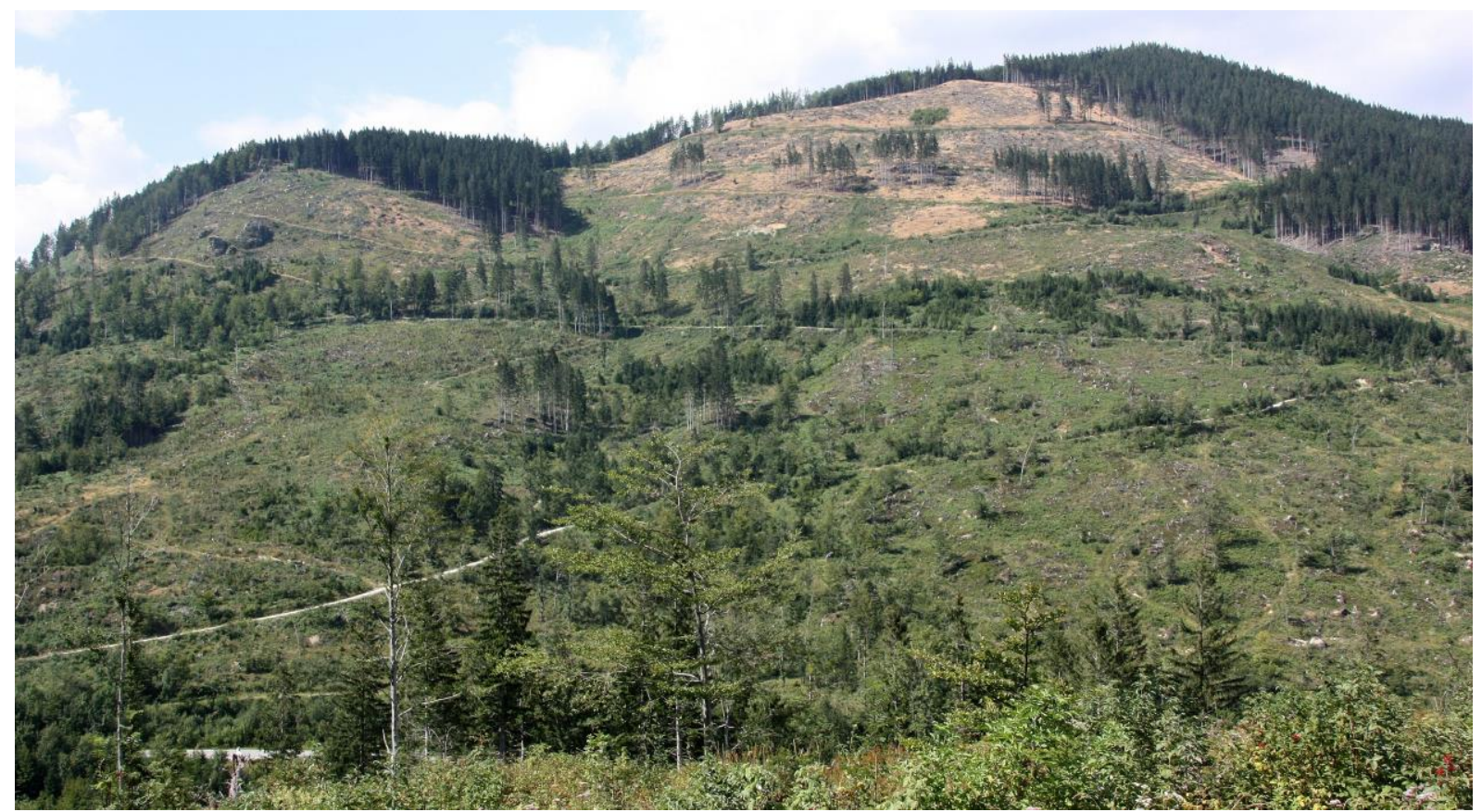

Fig. B.2 Southern aspect of the Crnivec windthrow area (87 ha) in June 2012. The highest parts (light grey or brown in colour) were overgrown with dense grass coverage, mostly Deschampsia flexuosa (L.) Trin., and poorly regenerated. The figure also illustrates the 
importance of pre-disturbance regeneration, which was developed in more structured stands.

The sampling design ensured that these parts were avoided.

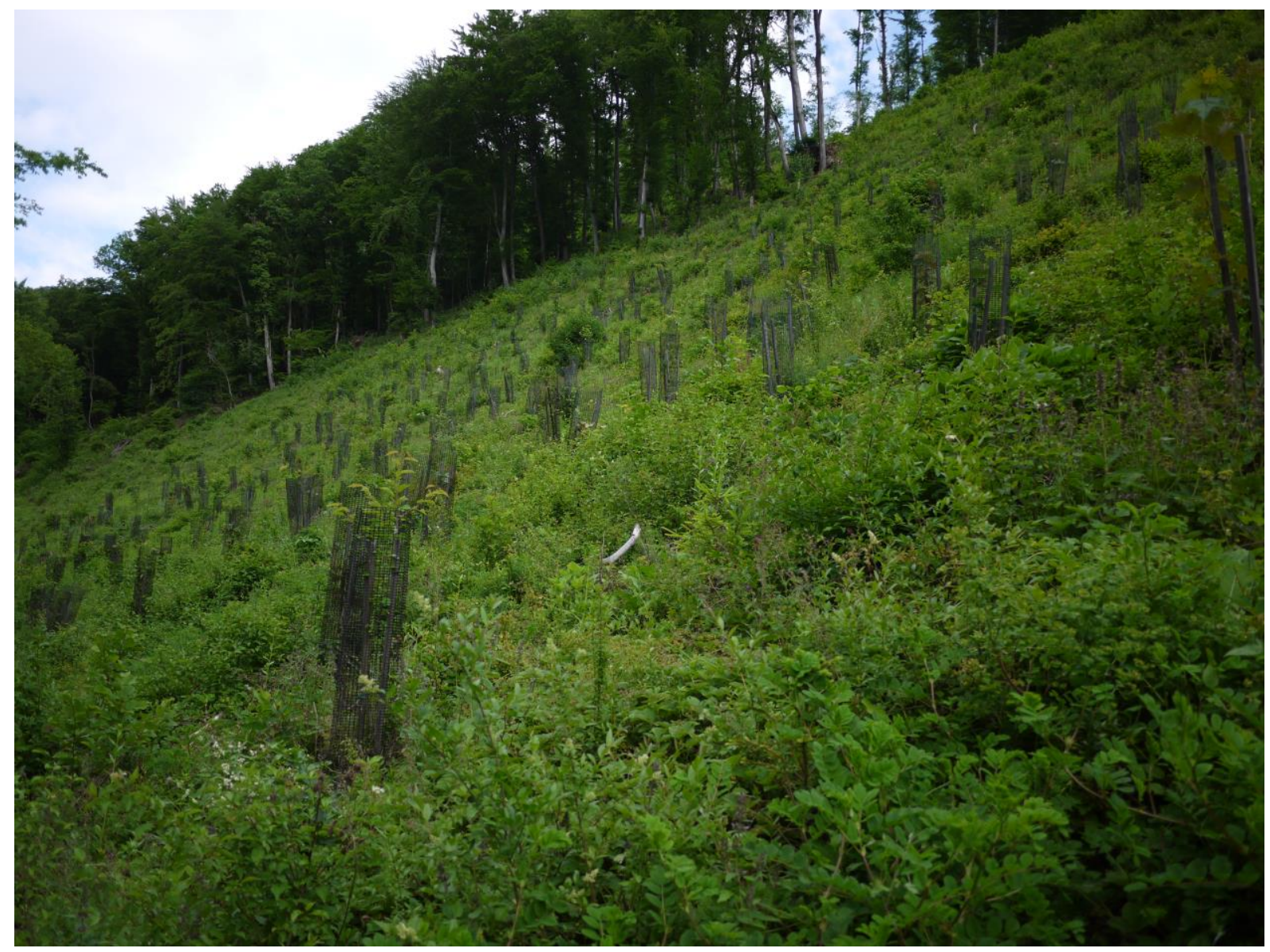

Fig. B.3 Windrow at a low altitude (300 $\mathrm{m}$ a.s.1.) in the Bohor area in May 2012. Three of four sampled windrow patches in the Bohor area were at low altitudes, and the parent material is mixed. Therefore, the regeneration was well developed. 


\section{Appendix C: English and Latin names of tree and shrub species found within windthrow openings}

\begin{tabular}{|c|c|}
\hline Pioneer tree species & Shade-tolerant tree species \\
\hline Aspen (Populus tremula L.) & European beech (Fagus sylvatica) \\
\hline Goat villow (Salix caprea L.) & Norway spruce (Picea abies (L.) H. Karst.) \\
\hline Silver birch (Betula pendula Roth) & Silver fir (Abies alba Mill.) \\
\hline \multicolumn{2}{|l|}{ White willow (Salix alba L.) } \\
\hline Light-demanding tree species & Shrubs \\
\hline Common Walnut (Juglans regia L.) & Blackberry (Rubus fruticosus aggr.) \\
\hline \multicolumn{2}{|l|}{ European hop-hornbeam (Ostrya carpinifolia } \\
\hline \multicolumn{2}{|l|}{ Scop.) } \\
\hline Field maple (Acer campestre L.) & European raspberry (Rubus idaeus L.) \\
\hline Manna ash (Fraxinus ornus L.) & Field rose (Rosa arvensis Huds.) \\
\hline Rowan (Sorbus aucuparia L.) & Red elderberry (Sambucus racemosa L.) \\
\hline Sessile oak (Quercus petraea (Matt.) Liebl.) & Clematis vitalba $\mathrm{L}$. \\
\hline Sycamore maple (Acer pseudoplatanus L.) & Italian woodbine (Lonicera caprifolium L.) \\
\hline Whitebeam (Sorbus aria Crantz) & Common dogwood (Cornus sanguinea L.) \\
\hline Wild cherry (Prunus avium L.) & Common privet (Ligustrum vulgare L.) \\
\hline \multirow[t]{7}{*}{ Wych elm (Ulmus glabra Huds.) } & Common hazel (Corylus avellana L.) \\
\hline & Elder (Sambucus nigra L.) \\
\hline & Mezereon (Daphne mezereumL.) \\
\hline & Spindle (Euonymus europaeus L.) \\
\hline & Alpine Honeysuckle (Lonicera alpigena L.) \\
\hline & Bitter wilow (Salix elaeagnos Scop.) \\
\hline & Common hawthorn (Crataegus laevigata Jacq.) \\
\hline
\end{tabular}




\section{References}

Aeschimann, D., Lauber, K., Moser, D.M. and Theurillat, J.-P. 2004. Flora Alpina: ein Atlas sämtlicher 4500 Gefässpflanzen der Alpen. Haupt Verlag: Bern, 2670 pp.

Anonymus 2009 Report on Forests. Slovenia Forest Service, p. 134 (in Slovene).

Aussenac, G., 2000. Interactions between forest stands and microclimate: Ecophysiological aspects and consequences for silviculture. Annals of Forest Science 57, 287-301.

Baier, R., Meyer, J. and Gottlein, A. 2007. Regeneration niches of Norway spruce (Picea abies L. Karst.) saplings in small canopy gaps in mixed mountain forests of the Bavarian Limestone Alps. European Journal of Forest Research 126, 11-22.

Balisky, A., Salonius, P., Walli, C., Brinkman, D., 1995. Seedling roots and forest floor: Misplaced and neglected aspects of British Columbia's reforestation effort? The Forestry Chronicle 71, 5965.

Bates, D., Mächler, M., Bolker, B. and Walker, S. 2015. Fitting linear mixed-effects models using lme4. Journal of Statistical Software 67, 1-48.

Belli, K.L., Hart, C.P., Hodges, J.D. and Stanturf, J.A. 1999. Assessment of the regeneration potential of red oaks and ash on minor bottoms of Mississippi. South. J. Appl. For. 23, 133-138.

Bolker, B., Skaug, H., Magnusson, A. and Nielsen, A. 2013. Getting started with the glmmADMB package. http://glmmadmb.r-forge.r-project.org/glmmADMB.pdf (accessed on 1 December, 2016).

Brang, P. 1998. Early seedling establishment of Picea abies in small forest gaps in the Swiss Alps. Canadian Journal of Forest Research 28, 626-639.

Brang, P. 2001. Resistance and elasticity: promising concepts for the management of protection forests in the European Alps. Forest Ecology and Management 145, 107-119.

Brang, P., Hilfiker, S., Wasem, U., Schwyzer, A. and Wohlgemuth, T. 2015. Langzeitforschung auf Sturmflächen zeigt Potenzial und Grenzen der Naturverjüngung. Schweiz. Z. Forstwes. 166, $147-158$. 
Brang, P., Schönenberger, W. and Fischer, A. 2004. Reforestation in Central Europe: Lessons from multi-disciplinary field experiments. For. Snow Landsc. Res. 78, 53-69.

Čater, M., Diaci, J., 2017. Divergent response of European beech, silver fir and Norway spruce advance regeneration to increased light levels following natural disturbance. Forest Ecology and Management 399, 206-212.

Cunningham, C., Zimmermann, N.E., Stoeckli, V. and Bugmann, H. 2006. Growth of Norway spruce (Picea abies L.) saplings in subalpine forests in Switzerland: Does spring climate matter? Forest Ecology and Management 228, 19-32.

Davidson, D.W., 1993. The effects of herbivory and granivory on terrestrial plant succession. Oikos $68,23-35$.

De Cáceres, M.D. and Legendre, P. 2009. Associations between species and groups of sites: indices and statistical inference. Ecology 90, 3566-3574.

De Chantal, M. and Granström, A. 2007. Aggregations of dead wood after wildfire act as browsing refugia for seedlings of Populus tremula and Salix caprea. Forest Ecology and Management $250,3-8$.

Diaci, J. 1996. Untersuchungen in slowenischen Totalwaldreservaten am Beispiel des Reservates "Požganija" (Brandfläche) in den Savinja-Alpen. Schweiz. Z. Forstwes. 147, 83-97.

Diaci, J. 2002. Regeneration dynamics in a Norway spruce plantation on a silver fir-beech forest site in the Slovenian Alps. Forest Ecology and Management 161, 27-38.

Diaci, J., Roženbergar, D., Fidej, G., Nagel, T.A., 2017. Challenges for uneven-aged silviculture in restoration of post-disturbance forests in Central Europe: A synthesis. Forests 8, 378-398.

Diekmann, M. 2003. Species indicator values as an important tool in applied plant ecology - a review. Basic and Applied Ecology 4, 493-506.

Dufrene, M. and Legendre, P. 1997. Species assemblages and indicator species: The need for a flexible asymmetrical approach. Ecological Monographs 67, 345-366.

Eichrodt, R. 1969. Über die Bedeutung von Moderholz für die natürliche Verjüngung im subalpinen Fichtenwald. Diss. ETH Zürich, Bühler Buchdruck: Zürich, 123 pp. 
Fidej, G. 2016. Post-disturbance treatments and stand restoration success in beech forest sites. $\mathrm{PhD}$ thesis. Biotechnical faculty, University of Ljubljana, Ljubljana, 116 pp.

Fischer, A., Lindner, M., Abs, C. and Lasch, P. 2002. Vegetation dynamics in central European forest ecosystems (near-natural as well as managed) after storm events. Folia Geobotanica 37, 17-32.

Fox, J. and Weisberg, S. 2011. An R companion to applied regression. Sage Publications: Thousand Oaks, California, 449 pp.

Haeussler, S., Bedford, L., Leduc, A., Bergeron, Y. and Kranabetter, J.M. 2002. Silvicultural disturbance severity and plant communities of the southern Canadian boreal forest. Silva Fennica 36, 307-327.

Hanssen, K.H. 2003. Natural regeneration of Picea abies on small clear-cuts in SE Norway. Forest Ecology and Management, 180, 199-213.

Heurich, M. 2009. Progress of forest regeneration after a large-scale Ips typographus outbreak in the subalpine Picea abies forests of the Bavarian Forest National Park. Silva Gabreta, 15 (1) 49-66.

Holgen, P. and Hanell, B. 2000. Performance of planted and naturally regenerated seedlings in Picea abies-dominated shelterwood stands and clear-cuts in Sweden. Forest Ecology and Management $127,129-138$

Ilisson, T., Koster, K., Vodde, F. and Jogiste, K. 2007. Regeneration development 4-5 years after a storm in Norway spruce dominated forests, Estonia. Forest Ecology and Management 250, $17-$ 24.

Jacobs, D.F., Ross-Davis, A.L. and Davis, A.S. 2004. Establishment success of conservation tree plantations in relation to silvicultural practices in Indiana, USA. New For. 28, 23-36.

Jonasova, M. and Prach, K. 2004. Central-European mountain spruce (Picea abies (L.) Karst.) forests: regeneration of tree species after a bark beetle outbreak. Ecological Engineering 23, 15-27.

Jost, L. 2006 Entropy and diversity. Oikos 113, 363-375.

Kramer, K., Brang, P., Bachofen, H., Bugmann, H. and Wohlgemuth, T. 2014. Site factors are more important than salvage logging for tree regeneration after wind disturbance in Central European forests. Forest Ecology and Management 331, 116-128. 
Kulakowski, D., Seidl, R., Holeksa, J., Kuuluvainen, T., Nagel, T.A., Panayotov, M. et al. 2016. A walk on the wild side: Disturbance dynamics and the conservation and management of European mountain forest ecosystems. Forest Ecology and Management. http://dx.doi.org/10.1016/j.foreco.2016.07.037

Kupferschmid, A.D. and Bugmann, H. 2005. Effect of microsites, logs and ungulate browsing on Picea abies regeneration in a mountain forest. Forest Ecology and Management 205, 251-265.

Landolt, E., Bäumler, B., Erhardt, A., Hegg, O., Klötzli, F., Lämmler, W., et al. 2010. Flora indicativa: Ökologische Zeigerwerte und biologische Kennzeichen zur Flora der Schweiz und der Alpen. Haupt: Bern, 378 pp.

Leibundgut, H., 1982. Europäische Urwälder der Bergstufe. Haupt, Bern.

Leps, J. and Smilauer, P. 2003. Multivariate analysis of ecological data using CANOCO. Cambridge University Press: Cambridge, 269 pp.

Mansourian, S., Vallauri, D. and Dudley, N. 2005. Forest Restoration in Landscapes: Beyond Planting Trees. Springer: New York, 437 pp.

Milosavljevic, J., 2015. Regeneration ecology of old-growth forest Lom in Bosnia and Herzegovina. Graduate thesis, Biotechnical Faculty, University of Ljubljana, Ljubljana, pp. 64.

Mocalov, S.A. and Lässig, R. 2002. Development of two boreal forests after large-scale windthrow in the Central Urals. For. Snow Landsc. Res. 77, 171-186.

Nagel, T.A., Mikac, S., Dolinar, M., Klopčič, M., Keren, S., Svoboda, M., Diaci, J., Bončina, A., Paulic, V., 2017. The natural disturbance regime in forests of the Dinaric Mountains: A synthesis of evidence. Forest Ecology and Management 388, 29-42.

Noble, D.L. and Alexander, R.R. 1977. Environmental Factors Affecting Natural Regeneration Engelmann Spruce in the Central Rocky Mountains. Forest Science 23, 420-429.

O'Hara, K.L., Ramage, B.S., 2013. Silviculture in an uncertain world: utilizing multi-aged management systems to integrate disturbance. Forestry 86, 401-410.

Oksanen, J., Blanchet, F.G., Kindt, R., Legendre, P., Minchin, P.R., O’Hara, R.B., Simpson, G.L., Solymos, P., Stevens, M.H.H., Wagner, H., 2013. Vegan: Community Ecology Package. R 
package version 2.0-10. http://CRAN.Rproject.org/package=vegan (accessed on 1 December 2016).

Peterson, C.J. and Leach, A.D. 2008. Salvage logging after windthrow alters microsite diversity, abundance and environment, but not vegetation. Forestry 81 (3), 361-376.

Pickett, S.T.A., White, P.S. (Eds.), 1985. The Ecology of Natural Disturbance and Patch Dynamics. Academic press inc., Orlando.

Pinheiro, J.C. and Bates, D.M. 2000. Mixed Effects Models in S and S-PLUS. Springer: New York, $528 \mathrm{pp}$.

Pommerening, A. and Murphy, S.T. 2004. A review of the history, definitions and methods of continuous cover forestry with special attention to afforestation and restocking. Forestry 77, $27-$ 44.

Priewasser, K., Brang, P., Bachofen, H., Bugmann, H. and Wohlgemuth, T. 2013. Impacts of salvagelogging on the status of deadwood after windthrow in Swiss forests. European Journal of Forest Research, 132, 231-240.

Pröll, G., Darabant, A., Gratzer, G. and Katzensteiner, K. 2015. Unfavourable microsites, competing vegetation and browsing restrict post-disturbance tree regeneration on extreme sites in the Northern Calcareous Alps. European Journal of Forest Research 134, 1-16.

R Core Team, 2016. R: A Language and Environment for Statistical Computing. R Foundation for Statistical Computing, Vienna, Austria, http://www.R-project.org (accessed on 1 December 2016).

Robinson, A.P. and Hamann, J.D. 2011. Forest Analytics with R: an Introduction. Springer, 339 pp.

Rozman, A., Diaci, J., Krese, A., Fidej, G. and Roženbergar, D. 2015. Forest regeneration dynamics following bark beetle outbreak in Norway spruce stands: Influence of meso-relief, forest edge distance and deer browsing. Forest Ecology and Management 353, 196-207.

Ščap, S., Klopčič, M. and Bončina, A. 2013. Natural regeneration of forest stands after windthrow on the Jelovica Mountain. Gozdarski vestnik 71, 195-212.

Schönenberger, W. 2002. Post windthrow stand regeneration in Swiss mountain forests: the first ten years after the 1990 storm Vivian. For. Snow Landsc. Res. 77, 61-80. 
Schütz, J.-P., Saniga, M., Diaci, J., Vrska, T., 2016. Comparing close-to-nature silviculture with processes in pristine forests: lessons from Central Europe. Annales of Forest Science 73, $911-$ 921.

Schwitter, R., Sandri, A., Bebi, P., Wohlgemuth, T. and Brang, P. 2015. Lehren aus Vivian für den Gebirgswald-im Hinblick auf den nächsten Sturm. Schweiz. Z. Forstwes. 166, 159-167.

Seidl, R., Schelhaas, M.J. and Lexer, M.J. 2011. Unravelling the drivers of intensifying forest disturbance regimes in Europe. Global Change Biology 17, 2842-2852.

Senn, J. and Schönenberger, W. 2001. Zwanzig Jahre Versuchsaufforstung Stillberg: Überleben und Wachstum einer subalpinen Aufforstung in Abhängigkeit vom Standort. Schweiz. Z. Forstwes. $152,226-246$

Van Couwenberghe, R., Collet, C., Lacombe, E. and Gégout, J.-C. 2011. Abundance response of western European forest species along canopy openness and soil pH gradients. Forest Ecology and Management, 262, 1483-1490.

Wohlgemuth, T., Kull, P. and Wüthrich, H. 2002. Disturbance of microsites and early tree regeneration after windthrow in Swiss mountain forests due to the winter storm Vivian 1990. For. Snow Landsc. Res. 77, 17-47.

Zielonka, T. 2006. When does dead wood turn into a substrate for spruce replacement? J. Veg. Sci. 17, 739-746.

Zuur, A.F., Ieno, E.N., Walker, N.J., Saveliev, A.A. and Smith, G.M. 2009. Mixed Effects Models and Extensions in Ecology with R. Springer: New York, 574 pp. 